\title{
Reproductive biology of Ameerega trivittata (Anura: Dendrobatidae) in an area of terra firme forest in eastern Amazonia
}

\author{
Ellen Cristina Serrão ACIOLI ${ }^{1}$, Selvino NECKEL-OLIVEIRA ${ }^{2}$ \\ 1 Universidade Federal do Pará/Museu Paraense Emílio Goeldi, Programa de Pós Graduação em Zoologia, Av. Perimetral 1901/1907, Terra Firme, 66017-970, Belém, Pará, Brasil. \\ 2 Universidade Federal de Santa Catarina, Departamento de Ecologia e Zoologia, Centro de Ciências Biológicas, 88040-970, Florianópolis, Santa Catarina, Brasil. \\ * Corresponding author: ellenacioli@hotmail.com
}

\section{ABSTRACT}

The reproductive success of tropical amphibians is influenced by factors such as body size and the characteristics of breeding sites. Data on reproductive biology are important for the understanding of population dynamics and the maintenance of species. The objectives of the present study were to examine the abundance of Ameerega trivittata, analyze the use of microhabitats by calling males and the snout-vent length (SVL) of breeding males and females, the number of tadpoles carried by the males and mature oocytes in the females, as well as the relationship between the SVL of the female and both the number and mean size of the mature oocytes found in the ovaries. Three field trips were conducted between January and September, 2009. A total of 31 plots, with a mean area of 2.3 ha, were surveyed, resulting in records of 235 individuals, with a mean density of 3.26 individuals per hectare. Overall, $66.1 \%$ of the individuals sighted were located in the leaf litter, while $17.4 \%$ were perched on decaying tree trunks on the forest floor, $15.7 \%$ on the aerial roots of Cecropia trees, and $0.8 \%$ on lianas. Males were observed transporting a mean of 10.8 tadpoles on their backs. A significant correlation was found between the size of the females and the mean diameter of the oocytes. New data were collected on the size of oocytes and no pattern was found in the type of perches used by calling males of the different Ameerega species.

KEYWORDS: Calling site, oocyte size, sexual dimorphism, tadpole transportation.

\section{Biologia reprodutiva de Ameerega trivittata (Anura: Dendrobatidae) em uma área de terra firme na Amazônia Oriental}

\section{RESUMO}

O sucesso reprodutivo das espécies de anfíbios tropicais sofre influência de fatores como local de reprodução e tamanho do corpo dos reprodutores. Informaçóes sobre a biologia reprodutiva são importantes para entender a dinâmica populacional e a manutenção das espécies. Os objetivos deste estudo foram de verificar a abundância, o uso de microhabitat por machos, o comprimento rostro-cloacal (CRC) de machos e fêmeas em atividade reprodutiva, a quantidade de girinos transportados por machos e o número de oócitos maduros por fêmea, e relacionar o número de oócitos maduros e o tamanho médio dos oócitos maduros com o CRC da fêmea. Um total de 31 parcelas foi vistoriado, tamanho médio de 2,3 ha, e um registro de 235 indivíduos, média de 3,26 por hectare. Sessenta e seis por cento dos indivíduos avistados estavam na serapilheira, 17,4\% sobre troncos em decomposição no chão da floresta, $15,7 \%$ sobre raízes aéreas de Cecropia sp. e $0,8 \%$ sobre cipó. Foram observados machos transportando girinos no dorso, a média de girinos transportados foi de 10,80 por macho. A quantidade média de oócitos maduros no ovário das fêmeas foi de 20,17. Houve correlaçáo significativa entre o diâmetro médio dos oócitos e CRC. Neste estudo obtivemos dados novos relacionados ao tamanho médio de oócitos em fêmeas ativamente reprodutivas e observamos que o tipo de sítio de vocalização usado por machos varia entre as espécies do gênero Ameerega.

PALAVRAS-CHAVE: Local de vocalizaçáo, tamanho dos oócitos, dimorfismo sexual, transporte de girinos. 


\section{INTRODUCTION}

The reproductive success of tropical amphibians may vary in relation to the body size of the species and the characteristics of its breeding sites (Fellers 1979; Nascimento et al. 2001). Crump (1974) and Halliday and Tejedo (1995) observed a significant relationship between the body size of the female and the size of the spawn, indicating that larger animals make a relatively greater contribution to the subsequent generation. Data on reproductive biology are fundamentally important for the understanding of the population dynamics and conservation of species.

The dendrobatid amphibians are widely distributed in the Neotropics. These frogs lay their eggs in terrestrial nests, such as leaf litter, or arboreal phytotelmata (Duellman 1992; Grant et al. 2006). The parents typically take care of the eggs and once they hatch, the male, female or both parents transport the tadpoles on their backs to an appropriate location in which metamorphosis can be completed (Rico et al. 2004; Grant et al.2006). In Brazil, this family is represented by 26 species distributed in five genera, of which Ameerega is the second most diverse, with nine species (Segalla et al. 2012; Frost 2013).

The triple-striped poison-dart frog, Ameerega trivittata, is one of the most widely distributed species of the genus, occurring practically throughout the Amazon basin, including Bolivia, Brazil, Colombia, Ecuador, French Guiana, Guyana, Paraguay, Peru, Suriname, and Venezuela (Silverstone 1976; Grant et al. 2006; Frost 2013). In Peru, Roithmair (1994a) observed that the reproductive success of $A$. trivittata was related to the size of the territory defended by the male. Differences in the size of the territories of male $A$. trivittata may be related to structural features of the habitat, such as the types of substrate used for vocalization, which have implications for the reproductive success of the population. However, no published data are available on the use of microhabitats by the males or the reproductive characteristics of the females of this species.

The present study aimed to: (1) verify the density of Ameerega trivittata in an area of terra firme forest in the eastern Amazon basin, and (2) characterize the use of microhabitats by calling males, as well as recording (3) the body size (snoutvent length, SVL) of breeding males and females, (4) the number of mature oocytes carried by the females and the number of tadpoles carried by the males, and analyzing (5) the relationship between the SVL of the female and the number and mean size of the mature oocytes found in the ovaries.

\section{MATERIALS AND METHODS}

\section{Study site}

The present study was conducted in a 50,000 ha tract of terra firme rainforest in the municipality of Juruti, in the west of the Brazilian state of Pará (0209'08”S, 5605'32”W; Figure $1)$. This area is characterized by the presence of relatively large trees, which may reach $50 \mathrm{~m}$ in height, such as the Brazil-nut (Bertholletia excelsa), maçaranduba (Manilkara huberi), and pekea (Caryocar villosum), with an understory dominated by palms (Ribeiro et al. 2002). Clearings and forest edges are dominated by pioneer tree species, such as those of the genus Cecropia (Santos 2000).

Mean annual temperature is approximately $26^{\circ} \mathrm{C}$, while relative humidity is normally over $80 \%$ throughout the year. Mean annual rainfall is approximately $2200 \mathrm{~mm}$. The rainy season coincides with the period between December and May, with the drier season lasting from June to November (Moraes et al. 2005).

\section{Sampling and population density}

We collected samples during three field trips to the study area in 2009 (January 19-February 13; April 25-June 18; July 20-September 1). During the first two expeditions, we surveyed 31 transects, which were separated by a distance of at least $200 \mathrm{~m}$, in order to guarantee the independence of the samples. The sampled area in each transect varied from 1.2 ha to 3.7 ha $\left(x^{-}=2.3\right.$; ha \pm 0.7$)$ with a total area of 72 ha. We considered the population density, as the total number of recorded individuals, divided by the total sampled area.

We visited each transect once, with six transects being visited during the first expedition, and 25 during the second. As both expeditions took place during the same rainy season, we considered the transects to be spatial, but not temporal replicates.

The sampling procedure consisted of active searching for individuals of the species $A$. trivittata by two collectors during a period of 1 hour and 30 minutes (Martins and Oliveira 1998). We conducted the surveys between 06:00 - 18:00 $\mathrm{h}$, and recorded all the animals heard or sighted within the transect during the period of search. At the end of each search, we recorded the total length covered in each transect, in order to calculate the sampled area.

\section{Activity patterns and male calling sites}

For each individual sampled, the following data were recorded: (I) sex, (II) behavior of the individual when first sighted, (III) the substrate being used at first sighting, (IV) presence of temporary pools in the immediate vicinity, and (V) the height above the soil at which the individual was located. All the individuals found vocalizing were considered male, while the sex of the specimens not calling could not be determined in the field. When individuals were sighted, they were allocated to one of three activity categories: (I) motionless and silent; (II) motionless and calling, and (III) moving. The substrates were classified as leaf litter, decomposing tree trunk, aerial Cecropia roots, and liana. 


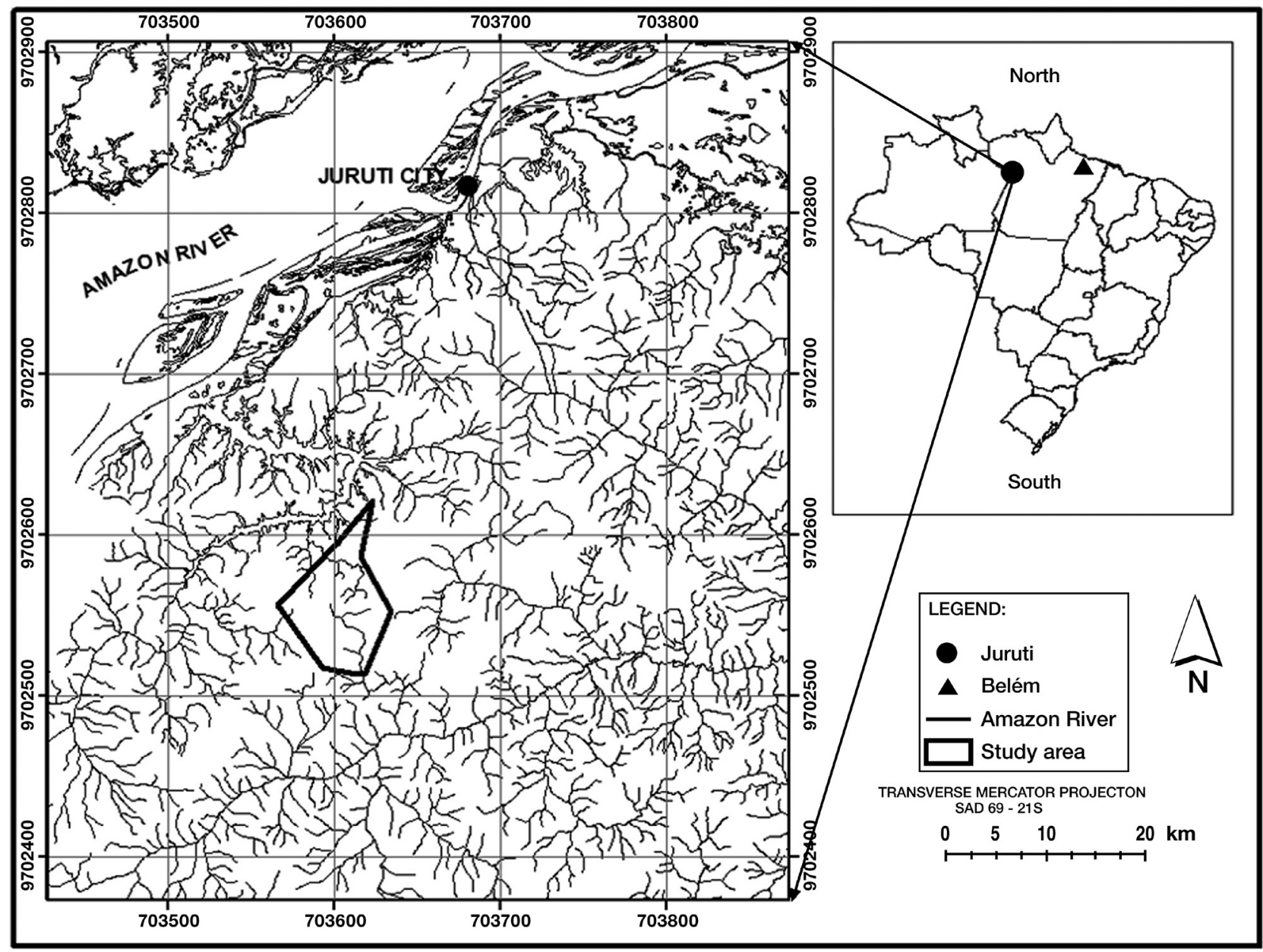

Figure 1. Location of Juruti in the Brazilian state of Pará (map, right) and the study area, demarcated by a dotted line (satellite image on the left).

\section{Female reproductive parameters and sexual dimorphism}

We collected a total of 60 Ameerega trivittata specimens, which we weighed using a Pesola ${ }^{\oplus}$ spring balance $(0.1 \mathrm{~g}$ precision, Baar, Swtizerland) and measured (SVL) with digital calipers $\left(0.5 \mathrm{~mm}\right.$ precision, Mitutoyo ${ }^{\oplus}$, Suzano, São Paulo, Brazil). We then euthanized the specimens in 5\% Lidocaine for analysis in the laboratory. Two of the specimens were considered to be juveniles and were not included in the analysis of reproductive status. Of the others, 28 were female, and 30, male. We analyzed all the specimens for the presence of longitudinal gular folds, which are typical of the males, but absent in the females (Roithmair 1994a). The males considered to be reproductively active presented two longitudinal gular folds, while females were registered as mature when they had grayish oocytes in the active vitellogenesis class and/or well-defined black and yellow poles, consistent with the post-vitellogenesis class (Díaz-Páez and Ortiz 2001). We used the $t$ test to evaluate the difference in body size between males and females.

We dissected the female specimens and removed their ovaries for the measurement of the number of mature oocytes and their mean diameter. We measured the diameter of the mature oocytes from the animal pole to the vegetal pole with digital calipers $\left(0.1 \mathrm{~mm}\right.$ precision, Mitutoyo ${ }^{\circledR}$, Suzano, São Paulo, Brazil). We examined the relationship between the quantity of mature oocytes and the SVL of the females only for the individuals with post-vitellogenesis class oocytes. The atrophied unspawned post-vitellogenesis class oocytes were not quantified or measured, and were thus excluded from the analysis. We used a simple linear regression to verify the possible relationship between body size (SVL) and the number and mean diameter of the oocytes observed in each female with a 5\% significance level. 


\section{Additional observations on resting sites and the number of tadpoles transported}

We dedicated the third expedition to nocturnal (18:00 22:00 h) and diurnal searches (06:00 - 18:00 h). The nocturnal searches were conducted for the collection of data on resting sites and the diurnal searches for the determination of the numbers of tadpoles being carried by the males. Resting individuals were detected with a flashlight along pre-existing trails. Each night, a trail of approximately $2 \mathrm{~km}$ was inspected. The resting site and height above the ground of each individual encountered was recorded. These data were not included in the census analysis.

During the diurnal searches, we collected data along five dirt roads that traverse the study area, varying in length from $1.4 \mathrm{~km}$ to $10 \mathrm{~km}$. The data were collected by two researchers over a one hour period, using a vehicle running at a constant speed of $5 \mathrm{~km}$ per hour. All individuals sighted carrying tadpoles were photographed before being captured in order to count the number of tadpoles being carried. We fixed all the specimens euthanized during the study in $10 \%$ formalin and then preserved them in $70 \%$ ethanol prior to depositing them in the herpetological collection of the Goeldi Museum (Museu Paraense Emílio Goeldi) in Belém, Pará state, Brazil.

\section{RESULTS}

\section{Population density, activity patterns, and male calling sites}

We recorded 235 individuals in the 31 transects, with a mean of 3.26 individuals per hectare, of which 118 were only heard vocalizing, and registered as males. The remaining 117 individuals were sighted, of which 36 were vocalizing and could thus also be recorded as males, while the sex of the other 81 was undetermined. Temporary ponds were observed in only two of the 31 transects. In one of these, we observed nine temporary ponds, while we found six in the other plot. The plot with nine ponds presented the highest abundance of $A$. trivittata $(n=31)$, whereas the plot with six ponds presented the third highest abundance $(n=16)$. Ameerega trivittata tadpoles were found in $86.76 \%$ of the ponds. The surface area of the ponds varied from $0.01 \mathrm{~m}^{2}$ to $24.63 \mathrm{~m}^{2}$ $\left(\bar{x}=1.71 \mathrm{~m}^{2} \pm 6.33\right)$.

Overall, $66.6 \%$ of the individuals sighted were in the leaf litter when observed, $17.1 \%$ were located in decomposing tree trunks on the forest floor, $15.5 \%$ were observed on aerial Cecropia roots, and $0.8 \%$ on lianas. With regard to activity patterns, almost half (44.4\%) of the individuals were resting in silence, $29.1 \%$ were calling, and $26.5 \%$ were moving (Table 1). The males were calling on perches, at heights of between 10 $\mathrm{cm}$ and $110 \mathrm{~cm}(\overline{\mathrm{x}}=44.60 \mathrm{~cm} \pm 24.60)$. Half of the perches used by these males were Cecropia roots, $46.9 \%$ were decaying trunks on the forest floor, and 3.1\% were lianas (Table 2).
Table 1. Substrate used by Ameerega trivittata in an area of terra firme forest in eastern Amazonia and the activity of the individuals at the moment of sighting.

\begin{tabular}{lccccc}
\hline \multicolumn{5}{c}{ Number (\%) of Ameerega trivittata individuals sighted } \\
\hline Substrate & Number & $(\%)$ & Activity category & Number & $(\%)$ \\
\hline Leaf litter & 78 & 66.6 & $\begin{array}{c}\text { Motionless and } \\
\text { silent }\end{array}$ & 52 & 44.4 \\
$\begin{array}{l}\text { Decomposing } \\
\text { tree trunk }\end{array}$ & 20 & 17.1 & $\begin{array}{c}\text { Motionless and } \\
\text { calling }\end{array}$ & 34 & 29.1 \\
$\begin{array}{l}\text { Aerial Cecropia } \\
\text { roots }\end{array}$ & 18 & 15.5 & Moving & 31 & 26.5 \\
Liana & 1 & 0.8 & & & \\
Total & 117 & 100 & Total & 117 & 100 \\
\hline
\end{tabular}

Table 2. Calling perches being used by male Ameerega trivittata when sighted in an area of terra firme forest in eastern Amazonia.

\begin{tabular}{lcc}
\hline \multicolumn{3}{c}{ Calling perches used by Ameerega trivittata } \\
\hline Perch & Number & $(\%)$ \\
\hline Cecropia roots & 16 & 50.0 \\
Decaying trunk tree & 15 & 46.9 \\
Liana & 1 & 3.1 \\
Total & 32 & 100 \\
\hline
\end{tabular}

\section{Female reproductive parameters and sexual dimorphism}

Of the 28 females collected, $89.3 \%$ had AV and/or PV type oocytes, and were thus considered to be reproductively active. The number of non-atrophied PV oocytes recorded per female ranged from 3 to $39(\bar{x}=20.17 \pm 8.80 ; n=17)$, although no significant relationship was found between female SVL and the number of mature oocytes $\left(r^{2}=0.04 ; P=0.42\right.$; Figure 2$)$.

The diameter of mature oocytes varied from 1.69 to 3.88 $\mathrm{mm}(\bar{x}=2.51 \mathrm{~mm} \pm 0.42 ; n=17)$, and the mean diameter was correlated significantly with female size, i.e., $\operatorname{SVL}\left(r^{2}=0.58 ; P=\right.$ 0.01 ; Figure 3). Twenty-eight of the 30 male specimens were mature. The SVL of the males ranged from 32.02 to 43.21 $\mathrm{mm}(\bar{x}=38.19 \mathrm{~mm} \pm 2.46 ; n=28)$ and that of the mature females from 39.88 to $46.37 \mathrm{~mm}\left(\bar{x}^{-}=42.87 \mathrm{~mm} \pm 1.66 ; n\right.$ $=25)$. On average, then, females were $4.68 \mathrm{~mm}$ longer than males $(t=8.00 ; P<0.01$; Figure 4$)$.

\section{Additional observations on resting sites and the number of tadpoles transported}

We encountered a total of $43 \mathrm{~A}$. trivittata along the road transects, of which, 10 were males transporting tadpoles on their backs. These males were carrying between two and 23 tadpoles $(\bar{x}=10.8 \pm 8.8 ; n=10)$.

We encountered a further 10 individuals during informal nocturnal surveys, sleeping at heights of between zero and 


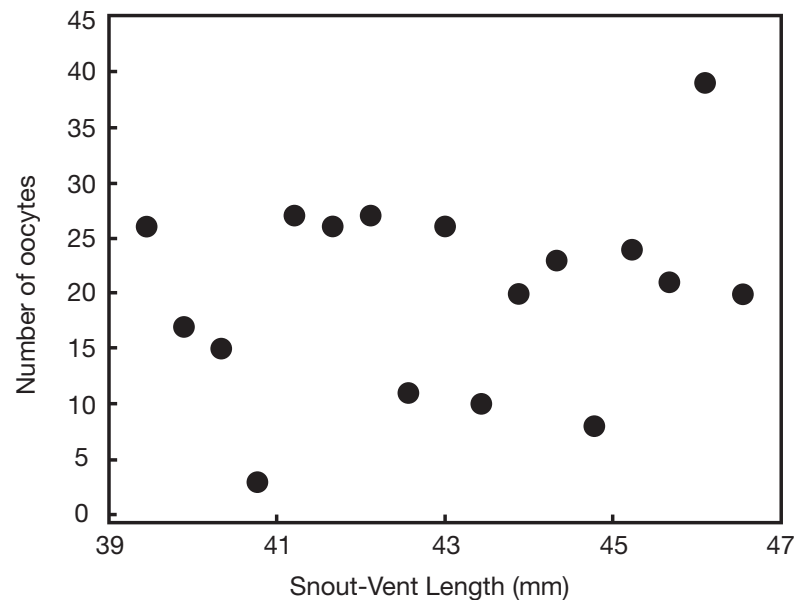

Figure 2. Relationship between the number of mature oocytes and the snoutvent length (SVL) of Ameerega trivittata females from a terra firme forest in the eastern Amazon basin.

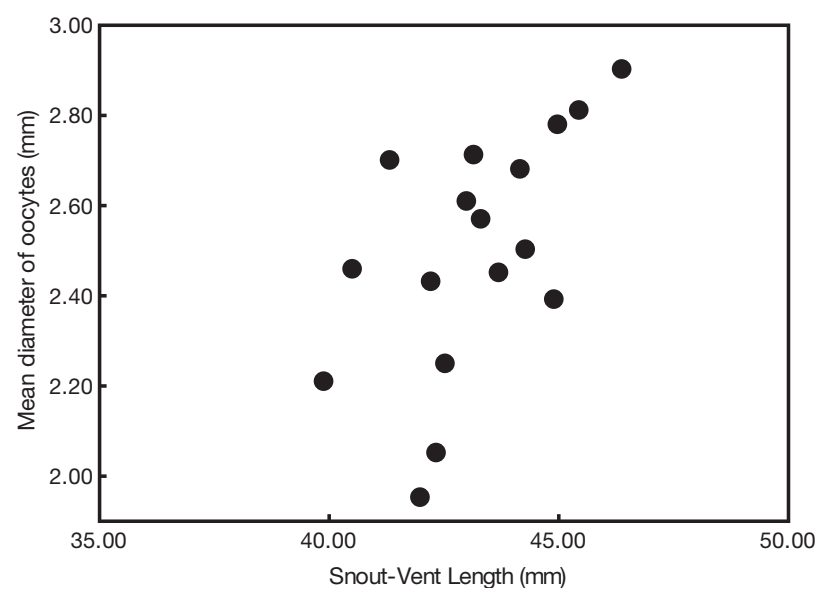

Figure 3. Relationship between the mean diameter of the oocytes and the snout-vent length (SVL) of Ameerega trivittata females from a terra firme forest in the eastern Amazon basin.

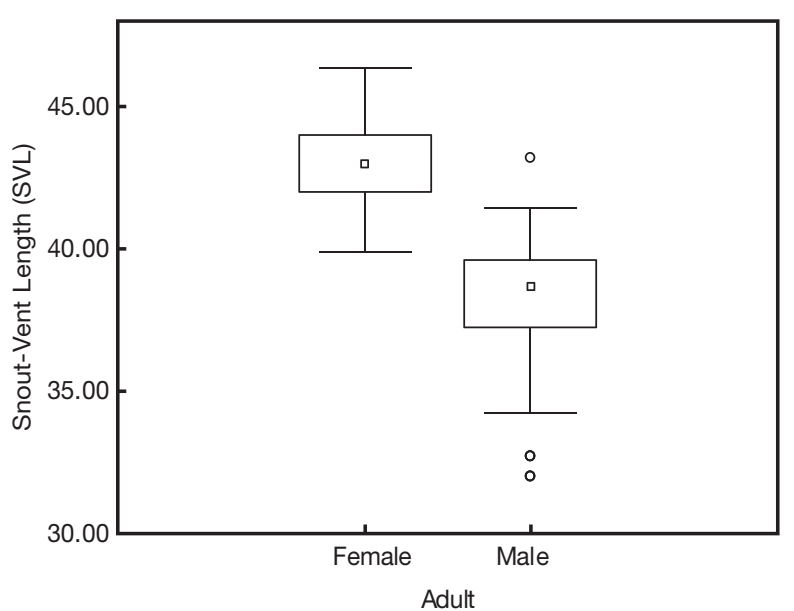

Figure 4. Snout-vent length (SVL) of adult male and female Ameerega trivittata from a terra firme forest in the eastern Amazon basin.
$60 \mathrm{~cm}$ above the ground $\left(x^{-}=30.00 \mathrm{~cm} \pm 21.08\right)$. Eight of these individuals were resting on the leaves of shrubs (one of which had seven tadpoles on its back), one was sleeping on a palm leaf, and the other in the leaf litter. No A. trivittata were observed calling or moving after 19:00 h. All individuals observed after this time were registered as sleeping.

\section{DISCUSSION}

Interspecific differences in anuran calling sites may be related primarily to the size and morphology of the animal (Bertoluci and Rodrigues 2002) and the local availability of perches. Cecropia roots and decaying trunks were probably used frequently as perches by calling males in the present study due to local availability. The use of perches raised up off the ground by calling $A$. trivittata males is not a typical behavioral pattern in this amphibian family. In Cerrado savanna, for example, Forti et al. (2010) observed that most Ameerega braccata called from the leaves of bushes and herbaceous plants. Haddad and Martins (1994) observed that Ameerega flavopicta usually call from rocks near streams, Ameerega hahneli from the leaf litter, and A. picta from the branches of dead trees on the leaf litter. Whilst, Brown and Towmey (2009) in a research conducted in north-central Peru recorded that Ameerega yoshina males appear to call from the leaf litter and Ameerega pepperi males call from elevated positions on boulders.

In the present study, no significant relationship was found between female SVL and the number of mature oocytes. This is consistent with the results of Roithmair (1994b), but not with other studies (e.g. Halliday and Tejedo 1995). Reproductive success in female amphibians is generally related to their SVL, with larger females producing more offspring than smaller ones. However, intraspecific variation in reproductive output of anurans may be related to variation in female properties and environmental conditions (Lüddecke 2002). Another point is that some comparative studies have indicated that egg size increases in the presence of parental care (e.g. Crump 1995; Crump 1996). The positive relationship observed in the present study between female size and the size of the eggs indicates that A. trivittata females may invest more in the size of the yolk than the number of oocytes.

Most species of dendrobatids transport their larvae or tadpoles to different locations to prevent cannibalism, while also enhancing dispersal. The mean number of tadpoles being carried by $A$. trivittata males was equivalent to half the mean number of mature oocytes found in the ovaries of the females. The deposited eggs of frogs are exposed to multiple factors such as predation by invertebrates, desiccation, and fungal attack. Assuming that all oocytes hatch, a larger number of tadpoles would be expected to be transported by the males, as observed in A. trivittata by Roithmair (1994b). This 
suggests that the males either do not remove all the tadpoles all at once or deposit them in different pools. In this case, a male may be found carrying different numbers of tadpoles at any given moment, depending on the stage of the transfer process. Alternatively, some of the tadpoles may be lost during transportation, or not all oocytes hatch.

In some species, the males may carry the tadpoles for a number of days before finding a temporary pool (Wells 1980), which would account for the individuals found sleeping at night with tadpoles on their backs, as observed in the present study, in which one male was observed sleeping with 10 tadpoles on its back on a fallen tree trunk $30 \mathrm{~cm}$ above the ground. However Roithmair (1994b) recorded a different pattern - in all but one case, all the tadpoles of a given clutch were transported together. In the one exception, the male transported 24 tadpoles on the first day and returned on the following day to retrieve the remaining eight tadpoles. The transportation of varying numbers of tadpoles has also been observed in the congeneric species, Ameerega flavopicta by Toledo et al. (2004), and Ameerega hahneli by Haddad and Martins (1994).

\section{CONCLUSION}

This study presents new data on the size of the oocytes of Ameerega trivittata, as well as the relationship between oocyte size and SVL. The sexual dimorphism observed in the study was typical of the dendrobatids in general. The use of perches above the ground for calling is also typical of the genus Ameerega, although the type of substrate used-Cecropia roots and fallen trunks - are different from those used by other species. More detailed data on the other species that inhabit the same biome, such as Ameerega hahneli, A. petersi, and $A$. picta, would provide a more reliable basis for the understanding of phylogenetic patterns in this group.

\section{ACKNOWLEDGMENTS}

We thank João Carlos, Fabrício Correa, Heriberto Figueira, and Marcelo Viana for their assistance in both the field and the laboratory. We would also like to thank Taran Grant, Marcelo Menin, Ulisses Gallati, Gleomar Maschio, Maria C. Santos-Costa, Paulo Bernardes, Felipe Toledo, and Domingos J. Rodrigues for their suggestions. We are also grateful to Rafael Salomão, coordinator of the fauna monitoring project, for making fieldwork possible, Alcoa World Alumina for financial support, and Coordenação de Aperfeiçoamento de Pessoal de Nível Superior (CAPES) for providing a scholarship. Specimen collection was authorized by Instituto Brasileiro do Meio Ambiente e dos Recursos Naturais Renováveis (IBAMA), special license number 02018/001126/07.

\section{REFERENCES}

Bertoluci, J.; Rodrigues, M. T. 2002. Utilização de habitats reprodutivos e micro-habitats de vocalização em uma taxocenose de anuros (Amphibia) da Mata Atlântica do sudeste do Brasil. Papéis Avulsos de Zoologia, 42: 287-297.

Brown, J.; Twomey, E. 2009. Complicated histories: three new species of poison frogs of the genus Ameerega (Anura: Dendrobatidae) from north-central Peru. Zootaxa, 2049: 1-38.

Crump, M. L. 1974. Reproductive strategies in a tropical anuran community. Miscellaneous Publication of the Museum of Natural History of the University of Kansas, 61: 1-68.

Crump, M. L. 1995. Parental care. In: Amphibian biology. Heatwole, H. Sullivan, B. K. (Ed.) Social behavior. v.2. Surrey Beatty and Sons, Chipping Norton, New South Wales, Australia, p. 518-567

Crump, M. L. 1996. Parental care among the amphibia. Advances in the Study of Behavior, 25: 109-144.

Díaz-Páez, H.; Ortiz; J. C. 2001. The reproductive cycle of Pleurodema thaul (Anura, Leptodactylidae) in central Chile. Amphibia-Reptilia, 22: 431-445.

Duellman, W. E. 1992. Reproductive strategies of frogs. Scientific American, 267: 58-65.

Fellers, G. M. 1979. Agression, territoriality, and mating behaviour in North American treefrogs. Animal Behaviour, 27: 107-119.

Forti, L. R.; Strussmann, C.; Mott, T. 2010. Acoustic communication and vocalization microhabitat in Ameerega braccata (Steindachner, 1864) (Anura, Dendrobatidae) from Midwestern Brazil. Brazilian Journal of Biology, 70: 211-216.

Frost, D. R. 2013. Amphibian Species of the World: an Online Reference. Version 5.6 . http://research.amnh.org/herpetology/ amphibia/index.html. Accessed on 01/01/2014.

Grant, T.; Frost, D. R.; Caldwell, J. P; Gagliardo, R.; Haddad, C. F. B; Kok, P. J. R.; Means, B. D.; et al. 2006. Phylogenetic systematics of dart-poison frogs and their relatives (Anura: Athesphatanura: Dendrobatidae). Bulletin of the American Museum of Natural History, 299: 1-262.

Haddad, C.F.B.; Martins, M.1994. Four species of Brazilian poison frogs related to Epipedobates pictus (Dendrobatidae): taxonomy and natural history observations. Herpetologica, 50: 282-295.

Halliday, T.; Tejedo, M. 1995. Intrasexual selection and alternative mating behaviour. In: Heatwole, H.; Sullivan, B. K. (Ed). Amphibian Biology. Surrey Beatty and Sons, Australia, p. 419468.

Lüddecke, H. 2002. Variation and trade-off in reproductive output of the Andean frog Hyla labialis. Oecologia, 130: 403-410.

Martins, M.; Oliveira, M. E. 1998. Natural history of snakes in forests of the Manaus region, Central Amazonia, Brazil. Herpetological Natural History, 6: 78-150.

Moraes, B. C.; Costa, J. M. N.; Costa, A. C. L.; Costa, M. H. 2005. Variação espacial e temporal da precipitação no Estado do Pará. Acta Amazonica, 35: 207-214.

Nascimento, L. B.; Carvalho, R. R.; Wogel, H.; Fernandes, D. S.; Feio, R. N. 2001. Reprodução e descrição do girino de 
Physalaemus rupestris (Caramaschi, Carcerelli e Feio, 1991) (Amphibia, Anura, Leptodactylidae). Boletim do Nacional. Zoologia, 450: 1-12.

Ribeiro, J. E. L.; Hopkins, M. J. G.; Vicentini, A.; Sothers, C. A.; Costa, M. A. S.; Brito, J. M.; et al. 2002. Flora da Reserva Ducke. $1^{\mathrm{a}}$ ed. Amazonas, Brasil, p.816.

Rico, M.; Rocha, C. F. D.; Borges Junior, V. N. T.; Sluys, M. V.2004. Breeding ecology of Scinax trapicheiroi (Anura, Hylidae) at a creek in the Atlantic Rainforest of Ilha Grande, southeastern Brazil. Amphibia-Reptilia, 25: 277-286.

Roithmair, M. E. 1994a. Male territoriality and female mate selection in the dart-poison frog Epipedobates trivittatus (Dendrobatidae, Anura). Copeia, 1: 107-115.

Roithmair, M. E. 1994b. Field studies on reproductive behaviour in two dart-poison frog species (Epipedobates femoralis, Epipedobates trivittatus) in Amazonian Peru. Herpetological Journal, 4: 77-85.

Santos, F. A. M. 2000. Growth and leaf demography of two Cecropia species. Revista Brasileira de Botânica, 23: 133-141.
Segalla, M. V.; Caramaschi, U.; Cruz, C. A. G.; Garcia, P. C. A.; Grant, T.; Haddad, C. F. B and Langone, J. 2012. Brazilian amphibians: list of species. http://www.sbherpetologia.org.br. Sociedade Brasileira de Herpetologia. Accessed on 25/04/2014.

Silverstone, P. A. 1976. A revision of the poison arrow frogs of the genus Phyllobates Bibron in Sagra (family Dendrobatidae). Natural History Museum of Los Angeles County Science Bulletin, 27: $1-53$.

Toledo, L. F.; Guimarães, L. D. A.; Lima, L. P.; Bastos, R. P.; Haddad, C. F. B. 2004. Notes on courtship, egg-laying site, and defensive behavior of Epipedobates flavopictus (Anura, Dendrobatidae) from two mountain ranges of central and southeastern Brazil. Phyllomedusa, 3: 145-147.

Wells, K. D. 1980. Behavioral ecology and social organization of a dendrobatid frog (Colostethus inguinalis). Behavioral Ecology and Sociobiology, 6: 199-209.

Recebido em 07/11/2013

Aceito em 08/05/2014 
